Expl Cell Biol. 1983;51:I-V

\title{
Contents, Vol. 51, 1983
}

\section{Vol. 51, 1983}

Experimental

Cell Biology

International Journal of Basic Pathology, Neoplasia, Immunology, Heterotransplantation and

Differentiation

Founded 1938 as 'Schweizerische Zeitschrift fur allgemeine Pathologie und Bakteriologie' by A. v. Albertini, A. Grumbach and H. Mooser, continued as 'Pathologia et Microbiologia'

\section{Editors}

\section{Pathology}

J.R. Rüttner, Zurich Neoplasia

G. V. Sherbet, Newcastle upon Tyne Immunology

H. Ramseier, Zurich Heterotransplantation

L. Helson, New York, N.Y. Differentiation

A. Wolsky, New York, NY.

Co-Editors

Pathology

R. Hess, Berne M. Kyogoku, Sendai M.A. Spycher, Zurich P. Vassalli, Geneva G. Zbinden, Zurich

Neoplasia

R.C. Coombes, Sutton F. Deinhardt, Munich

D. Glaves Rapp, Buffalo, NY.

I.R. Hart, Frederick, Md.

M.S. Lakshmi, Newcastle upon Tyne

Immunology

H. Binz, Zurich D.G. Braun, Basel

E. Diener, Edmonton

R.T. Smith, Gainesville, Fla. J. Sprent, Philadelphia, Pa. E. Wecker, Würzburg H. Wigzell, Uppsala R.M. Zinkernagel, Zurich

Heterotransplantation

B.C. Giovanella, Houston, Tex. D.P. Houchens, Columbus, Ohio I. Lefkovits, Basel T. Nomura, Kanagawa CO. Povlsen, Copenhagen N.D. Reed, Bozeman, Mont. J. Rygaard, Copenhagen S.

Shin, Bronx, N.Y. B.C.M. Sordat, Lausanne

Differentiation

M. Balls, Nottingham

J.A.M. van den Biggelaar, Utrecht

R. Chandebois, Marseille

G. Csaba, Budapest

S. Løvtrup, Umeå

D.J. Pizzarello, New York, N.Y. 
S. Ranzi, Milan

T. Yamada, Lausanne

S. Karger $\square$ Medical and Scientific Publishers $\cdot$ Basel $\cdot$ München $\cdot$ Paris $\square$ London $\cdot$ New York

Tokyo $\cdot$ Sydney

Drug Dosage

The authors and the publisher have exerted every effort to ensure that drug selection and dosage set forth in this text are in accord with current recommendations and practice at the time of publication. However, in view of ongoing research, changes in government regulations, and the constant flow of information relating to drug therapy and drug reactions, the reader is urged to check the package insert for each drug for any change in indications and dosage and for added warnings and precautions. This is particularly important when the recommended agent is a new and/or infrequently employed drug.

All

All rights reserved.

No part of this publication may be translated into other languages, reproduced or utilized in any form or by any means, electronic or mechanical, including photocopying, recording, microcopying, or by any information storage and retrieval system, without permission in writing from the publisher or, in the case of photocopying, direct payment of a specified fee to the Copyright Clearance Center (see 'Information for Readers and Subscribers').

(C) Copyright 1983 by S. Karger AG, P.O. Box, CH-4009 Basel (Switzerland)

Printed in Switzerland by Thür AG Offsetdruck, Pratteln

Contents Vol. 51,1983

No. 1 Early Fibrogenicity of Asbestos Fibers in Visceral Peritoneum

Winkler, G.C.; Rüttner, J.R 1

Exogenous Fibronectin Requirement for Adhesion by Neoplastic Human Cells

Rajaraman, R.; MacSween, J.M.; Murdock, C.A 9

Lectin-Defined Cell Surface Glycoconjugates of Pancreatic Cancer Cells and Their Nonmalignant Counterparts

Raedler, A.; Schmiegel, W.H.; Raedler, E.; Arndt, R.; Thiele, H.-G 19

Biological Activity of Synthetic Subunits of Streptococcus Peptidoglycan. II. Relation of Peptidoglycan Subunits and Analogues to Fever Effect and Induction of Tolerance

Rotta, J.; Zaoral, M.; Rýc, M.; Straka, R.; Jezek, J 29

Phorbol Myristate Acetate-Induced Macrophage Aggregation

Badenoch-Jones, P 39

Cellular Specificity of the Cure for Neonatal Osteopetrosis in the ia Rat

Schneider, G.B.; Byrnes, J.E 44

Blood Cells and Their Role in Regeneration. I. Changes in Circulating Blood Cell Counts during Forelimb Regeneration

Sicard, R.E 51

Book Reviews $\quad 60$

No. 2 Ultrastructure of Macrophages of the Murine Peyer's Patch Dome

Hammer, R.; Joel, D.D.; LeFevre, M.E 61

Inhibition of Bone Resorption and Increased Incorporation of 3H-Glucosamine into Hyaluronate in Bone Organ Cultures Treated with Dibutyryl Cyclic AMP and Colchicine

Severson, A.R 70 
The Role of Phosphatidylinositol Turnover in Initiation of Prostaglandin Biosynthesis in Concanavalin A-Induced Activation of Rat Peritoneal Macrophages

Matsubara, T.; Hirohata, K 77

Histopathologic Evaluation of Response to Treatment of Human Tumors Grown in the Nude Mouse

Kyriazis, A.A.; Kyriazis, A.P.; Kereiakes, J.G.; Soloway, M.S.; McCombs, W.B 83 Action of Adenosine Triphosphate on Human Skin and Gingival Fibroblasts. Protective Action of Fibronectin

Hakim, A.A 96

Blood Cells and Their Role in Regeneration. II. Effects of Putative Immunological

Manipulations on Circulating Blood Cell Counts during Regeneration

Sicard, R.E. , 109

The Effect of Oral Contraceptives on Sister Chromatid Exchange, Blast Transformation, Mitotic Index and Micronuclei Formation

Dutkowski, R.T.; Kevin, M.J.; Jenkins, E.C 115

IV

Contents

No. 3 Effects of Laminin, Fibronectin and Type IV Collagen on Liver Cell Cultures

Hirata, K.; Yoshida, Y.; Shiramatsu, K.; Freeman, A.E.; Hayasaka, H 121

Characteristics of Mast Cells in Chediak-Higashi Mice: Light and Electron Microscopic

Studies of Connective Tissue and Mucosal Mast Cells

Crowle, P.K.; Phillips, D.E 130

The Cell Surface Sulphydryl Content of Metastatic Variants of B16 Murine Melanoma

Sherbet, G.V 140

Mechanisms of Lysosomal Enzyme Secretion by Human U-937 Monocytes

Leoni, P.; Dean, R.T 148

Discrimination between Macrophage- and NK-Type Tumoricidal Activities via Anti-Asialo GM1 Antibody

Keller, R.; Bächi, T.; Okumura, K 158

Macrophage-Mediated Inhibition of Melanoma Cell Growth in Nude Mice

Adelman, D.C.; Erickson, K.L.; Gershwin, M.E 165

Light Microscopy Investigation of the Action of the Unsaponifiable Residue of Vegetable

Oils on Rat Periodontal Disease Induced by a High Carbohydrate Diet

Mattout, P.; Rachlin, G.; Maupu, H 172

Book Reviews 178

No. 4 Resistance and Susceptibility to Pulmonary Metastasis of Lewis Lung Carcinoma in Different Mouse Strains

Hergueux, J.; Bischoff, P.; Donner, M

181

Effects of Prostanoid Precursors and Indomethacin on Chick Embryonic Cartilage Growth in Organ Culture

Kirkpatrick, C.J.; Mohr, W.; Haferkamp, 0192

Uncontrolled Growth of Tumour Stromal Fibroblasts in vitro

Delinassios, J.G.; Kottaridis, S.D.; Garas, J 201

Effect of the Inhibition of Nucleic Acids and Protein Synthesis upon the Development of Melanotic Tumors in Drosophila

Ghelelovitch, S 210 
Characteristics of 85 Pediatric Tumors Heterotransplanted into Nude Mice

Neely, J.E.; Ballard, E.T.; Britt, A.L.; Workman, L 217

Induction of Somites by Myosin mRNA

Bolzern, A.M.; Cigada Leonardi, M.; De Bernardi, F.; Fascio, U.; Maci, R.; Ranzi, S.;

Sotgia, C 228

Book Review 239

Announcement

240

No. 5 Editorial

Cancer Research Reviews

Sherbet, G.V 241

Distribution of Surface Anionic Sites on Mouse Hybrid Myelomas

Marikovsky, Y.; Wang, L.; Inbar, M 242

Role of Prostaglandins in Metastatic Dissemination of Cancer. Minireview on Cancer

Research

Tisdale, MJ 250

Contents

$\mathrm{V}$

Studies on Thymocyte Subpopulations in Guinea Pigs. III. Physical and Functional Charac terization of Six Subpopulations Separated by Density Gradient Centrifugation and PNA

Binding

Sandberg, G.; Söder, O.; Kölare, S.; Ernström, U 257

Differentiation of Mononuclear Cells into Multinucleated Osteoclast-Like Cells

Severson, A.R 267

Erythroid Stem Cells in Rauscher Viral Erythroleukemia

Gallicchio, V.S.; Murphy, M.J., Jr 275

Bithorax Phenocopy and Pattern Formation. I. Spatiotemporal Characteristics of the Phenocopy Response

Ho, M.-W.; Bolton, E.; Saunders, P.T 282

Bithorax Phenocopy and Pattern Formation. II. A Model of Prepattern Formation

Ho, M.-W.; Saunders, P.T.; Bolton, E 291

Book Review 300

Errata 300

No. 6 Comparison between the Effect of Guanazole and Hydroxyurea on DNA Metabolism and DNA Repair of HeLa Cells

Partsch, G.; Neumüller, J 301

Effect of Hydrocortisone on the Proliferation of Cultured Skin Fibroblasts from Normal

Individuals and Individuals at High Risk of Colon Cancer

Kopelovich, L 308

Prolonged in vitro Maintenance of Human Diploid Fibroblasts in a New Tissue Culture

Medium (PRC-1)

Delinassios, J.G 315

Hydrophobic Affinity Cell Partition Detects Alterations in Surface Properties of Erythro-

cytes in Rats Bearing a Subcutaneous Leydig Cell Tumour

Gascoine, P.S.; Dix, C.J.; Fisher, D 322

Immunological Competence in Osteopetrotic (Microphthalmic) Mice

Schneider, G.B.; Marks, S.C., Jr 327 
Putative Immunological Influence upon Amphibian Forelimb Regeneration. I. Effects of Several Immunoactive Agents on Regeneration Rate and Gross Morphology

Sicard, R.E.; Laffond, W.T 337

Abnormal Eye Development in Drosophila after Treatment with Vinblastine

Wolsky, A 345

Author Index 352

Subject Index 353 